\title{
PRICES OF ORGANIC PRODUCTS IN THE REPUBLIC OF SERBIA
}

\section{Mirela Tomaš Simin ${ }^{1}$, Danica Glavaš Trbićc Marica Petrović ${ }^{3}$, Bojana Komaromi $^{4}$}

\begin{abstract}
In the paper, the authors analyse the organic system of agricultural production. Organic agriculture is a production system based on the principles of sustainable agriculture. Among other things, the need to integrate three basic aspects of sustainability - social, economic and environmental - is emphasized. In order to meet the economic viability organic production relies heavily on the so-called premium prices for these products. A survey of organic prices in the Republic of Serbia for the period 2012 to 2017 showed that premium prices in Serbia range from $50 \%$ to $300 \%$, depending on the type of product and its seasonality. The authors conclude that this is in line with developed markets for organic products.
\end{abstract}

Key words: organic production, premium prices, Republic of Serbia.

JEL ${ }^{5}$ : E31, F64, O13

\section{Introduction}

Organic production (in its present form) began its development almost a century ago, that is, in the 1920s, where it appeared in its original form as biodynamic production. Even then, producers expressed concern for the environment and the consequences that the intensive agriculture had on it. Increasing involvement of the chemical industry, especially after the so-called the Green Revolution, reaffirmed their views on the negative effects of the, then prevalent, mode of agricultural

1 Mirela Tomaš Simin, Ph.D., Assistant Lecturer, Faculty of Agriculture, University of Novi Sad, Trg Dositeja Obradovića no. 8, 21000 Novi Sad, Serbia, Phone: +381 2145035 14, E-mail: mirela.tomas@polj.edu.rs,

2 Danica Glavaš Trbić, M.Sc., Assistant Lecturer, Faculty of Agriculture, University of Novi Sad, Trg Dositeja Obradovića no. 8, 21000 Novi Sad, Serbia, Phone: +381 2145035 08, E-mail: danicagt@gmail.com

3 Marica Petrović, Ph.D., Assistant Lecturer, Faculty of Agriculture, University of Novi Sad, Trg Dositeja Obradovića no. 8, 21000 Novi Sad, Serbia, Phone: +381 214853 270, E-mail: maricam@polj.uns.ac.rs

4 Bojana Komaromi, Ph.D., Docent, Faculty of Agriculture, University of Novi Sad, Trg Dositeja Obradovića no. 8, 21000 Novi Sad, Serbia, Phone: +381 214853 506, E-mail: bojana.komaromi@gmail.com

5 Article info: Original Article, Received: 25 $5^{\text {th }}$ September 2019., Accepted: $1^{\text {st }}$ October 2019. 
production called conventional agriculture. The pioneers of organic farming were looking for ways to produce sufficient amounts of food that is health-safe and that can be used in human and animal nutrition without any negative consequences and that is at the same time environmentally friendly. These alternative directions of agricultural are called sustainable agriculture because it integrates three aspects of sustainability - social, environmental and economic sustainability (Tomaš Simin, 2019).

In this regard, some authors state that (Kovačević, 2005; Pejanović et al., 2009) sustainable agriculture must be defined as:

- economically viable: in today's market economy and consumer society, only economically viable agricultural production can be sustainable in the long term;

- environmentally friendly: contributes to the conservation of natural resources as the basis of agricultural production for future generations, while preserving or enhancing other ecosystems that are affected by agricultural activities (Jones, 2003). Sustainable agriculture is seen as ecosystem management based on the soil-plant-animal-human biological balance;

- socially acceptable: it fulfils the broader values of society, such as the high quality of life of the producers themselves, but also of the social community to which they belong, while preserving culture and tradition.

According to some research, globally, there are a growing number of consumers that purchase the organic and eco-products, while mentioned products are available in over than $70 \%$ of traditional stores (Sokolov Mladenović, 2017). On the other hand, this market is constantly and rapidly developing, e.g. in France is increasing at the annual rate of around 19\% (Živković et al., 2017).

Further development of organic production is closely linked to the inclusion of growing areas in this system, and an increasing number of producers. In addition to the environmental and social sustainability of this system of production, for its producers, especially in developing countries, its economic sustainability is of paramount importance. Premium prices available in this production are particularly attractive as well as the assumption that production costs are relatively lower than the conventional production system.

Offermann and Nieberg (2000) when researching and analysing prices of organic products, state that it is not possible to determine an identical unit price for an organic product originating from different holdings. The main reasons for this problem are:

- a large number of distribution channels in organic production where prices vary significantly depending on the channel selected; 
- prices vary far more between individual organic farms than farms in the conventional production system. This is also due to unequal access to the sales channels of different farms.

Some researcher (Jeong, Jang, 2019) are even discussing premium prices for restaurants that offer "organic menu" or effects that organic prices have on consumers (Rodiger, Hamm, 2015). However, in developing countries, the economic aspect of organic farming is one of the primary reasons for producers' decision to enter this production system. The availability of premium prices is of great importance.

In the paper, the authors assume that the prices of organic products in the Republic of Serbia are similar to those of the more developed markets. The starting hypothesis is that organic products in Serbia are characterized by premium prices. The aim of the research was to analyse these prices in the world scientific and professional literature, as well as to define premium prices in the Republic of Serbia.

\section{Methodology and used data}

During the research, sources of scientific literature related to the analysis of premium prices were used. Also, a survey was conducted in the Republic of Serbia to determine average premium prices for organic products. Average prices are the result of research and data collected in retail stores (Univer Export, Maxi, Tempo, Idea, DM drugstores), followed by green markets in Novi Sad and Belgrade, as well as the price of these products (organic) that are available through online sales, that is, on various websites that offer organic products.

The relative price was calculated by calculating a ratio between organic and conventional products individually for each year, where conventional production was the base value $(\mathrm{conv}=100)$.

\section{Results with discussion}

The prices of organic products on the market are, in most cases, higher than the prices of conventional products (Tomaš Simin, Miloradić, 2014). The higher prices defined in this way, i.e. premium prices as they are called in the literature, are a consequence of the conditions of supply and demand in the market of organic products. In developed countries, demand for organic products still outstrips supply. Consumers are prepared to pay premium prices for these products, provided that they imply that basic principles of organic farming are respected in production, which are guaranteed by the organic label. 
However, Anderson (1994) states in its research that not all certified organic producers in the US sell their products at premium prices. Some growers do not have access to the organic market and some farmers intentionally avoid selling at premium prices. Their reasons include a commitment to making organic food available to lowincome consumers and a desire to prove to other farmers that organic farming is not dependent on premium prices.

Premium prices for organic crops are widespread in Western European countries such as Britain, Germany, Denmark and Switzerland, but the size of the premium varies depending on the crop and country. For example, premiums for ground wheat range from $300 \%$ in Germany, more than $100 \%$ in Britain, to $40 \%$ in Switzerland, reflecting in this way the level of demand for organic food in each country and the level to which conventional prices are supported by agrarian policy (conventional wheat prices in Switzerland are three times higher than prices in the EU). Premium prices for livestock production are less available due to the underdevelopment of the market for organic livestock products and the problem of supply coordination. Where available, milk and meat premiums range from 10-25\% (Padel, Lampkin, 1994; Loke et al., 2015).

In the mentioned study Offermann and Nieberg (2000) gave an overview of the organic products' market prices in 18 EU member states. They found challenging to apprise the average premium prices, even in certain country for the reasons outlined above - the large number of organic product sales channels (among which prices vary significantly) on which producers have divergent entry. In the most EU states, organically produced wheat had average price 50 to $200 \%$ higher than conventionally produced wheat. Mentioned gap was even higher at potatoes, where price ranged from $50-500 \%$.

Average premium prices for organic livestock products are generally lower, as great part of organic products has to be usually realized at level of conventional prices. So, at EU level price of organic dairy products ranges from $8-36 \%$, for beef from $20-30 \%$, for pork from $20-70 \%$, with data varying significantly depending on the country analysed and region. Dabbert et al. (2003) state that both the distribution channels and the representation of organic products in a country's market is a significant factor affecting the level of premium prices. For example, the authors mentioned that premiums for fruits, potatoes and vegetables are high in countries such as Italy, Spain, Greece and Portugal despite domestic production, while in countries where organic products are sold in supermarkets (such as Austria, Denmark and Switzerland) these premiums are lower. 
Organic producer's find really significant for maintaining of their profitability to realize produced products at as high a price as possible. Mentioned is proved by study conducted in Germany and UK, where $40-75 \%$ of the gained profit at farm active in organic agriculture are made upon the higher prices. This share ranges from $10-50 \%$ at the households active in production of organic milk (Table 1.).

Table 1. Impact of premium prices on organic farm income

\begin{tabular}{|l|c|c|}
\hline \multirow{2}{*}{ Country } & \multicolumn{2}{|c|}{ Share of premium prices in profit (\%) } \\
\cline { 2 - 3 } & Farms with plant production & Dairy Farms \\
\hline Germany & 75 & 48 \\
\hline Great Britain & 40 & $10-17\left(51^{*}\right)$ \\
\hline Denmark & $/$ & $>45$ \\
\hline
\end{tabular}

Source: Nieberg, Offermann, 2003.

Note: *In the UK, the price differential between organically and conventionally produced milk increased rapidly in 1998, as a consequence of the drastic fall in the price of conventionally produced milk, following the revaluation of the British pound.

Prices of products obtained at the agricultural holdings involved in eco or organic production in Serbia have to be $10-30 \%$ higher in compare to prices of conventionally produced products. Mentioned is the lowest level of prices that could enable profitability to organic producers equal to profitability reached in conventional production (Sredojević, 2002).

The prices of organic products in the Republic of Serbia are increased compared to the prices of conventional products in the range of $50 \%$ to $300 \%$. The amount of premium price realized depends primarily on the type of product, point of sale and seasonality of the product. In recent years, the supply of organic products from imports has been increasing, especially when it comes to processed products. The first meat (beef) appeared on the market only in mid-2015, but it is still lacking in large quantities (one of the factors is certainly the relatively low demand on the domestic market for this type of product), and in 2013 they appeared on the market dairy products (fresh milk, yogurt, sour cream and cheese). Table 2 shows the relative prices (prices of conventional products $=100$ ) of selected organic products for the period 2012 to 2017. The presented average prices are the result of research and data collected at retail stores (Univer Export, Maxi, Tempo, Idea, DM drugstores), followed by green markets in Novi Sad and Belgrade, which also represent organic products (two markets), as well as the price of these products which are available through online sales, that is, on various websites that offer organic products ${ }^{6}$.

6 The data was accessed and used from the following pages: www.vegemarket.rs/index.html, www.biospajz.rs/index.php, http://natural-food.rs/o-us, http://organico.rs/, http://organskiproducts.com/index.php?lang=en, http://just-organic.rs/sveze organsko_voce i povrce.php 
Table 2. Relative prices of organic products in the Republic of Serbia in the period 2012-2017

\begin{tabular}{|c|c|c|c|c|c|c|}
\hline \multirow{2}{*}{ Product } & \multicolumn{6}{|c|}{ Relative prices $(\operatorname{conv}=100)$ by year } \\
\hline & 2012 & 2013 & 2014 & 2015 & 2016 & 2017 \\
\hline $\begin{array}{l}\text { Jam (wild blueberries, wild } \\
\text { strawberries, rosehip), (225g) }\end{array}$ & 146,98 & 142,92 & 136,68 & 131,81 & 125,73 & 127,34 \\
\hline $\begin{array}{l}\text { Jam (cornel-berry pomegranate), } \\
(375 \mathrm{~g})\end{array}$ & 111,58 & 104,60 & 113,37 & 125,47 & 117,56 & 114,20 \\
\hline Sweet (wild strawberry), (225g) & 238,16 & 242,37 & 254,01 & 241,05 & 241,40 & 246,92 \\
\hline Honey jars $(450 \mathrm{~g})$ & 208,97 & 212,49 & 231,09 & 221,70 & 247,80 & 246,12 \\
\hline Beetroot jar (400g) & 163,30 & 161,77 & 172,59 & 206,60 & 234,63 & 212,75 \\
\hline Apple juice $(750 \mathrm{ml})$ & 719,81 & 737,41 & 790,72 & 755,70 & 871,18 & 825,96 \\
\hline Carrot juice $(750 \mathrm{ml})$ & 164,45 & 160,30 & 166,17 & 164,68 & 169,74 & 171,50 \\
\hline Beet juice $(750 \mathrm{ml})$ & 104,40 & 108,55 & 107,25 & 110,19 & 107,29 & 112,13 \\
\hline Tomato juice $(250 \mathrm{ml})$ & 422,10 & 429,89 & 404,35 & 393,21 & 408,14 & 410,51 \\
\hline Wild Blackberry Juice $(200 \mathrm{ml})$ & - & - & 112,18 & 114,73 & 113,86 & 117,40 \\
\hline $\begin{array}{l}\text { Soy cheese tofu (smoked), } \\
(200 \mathrm{~g})\end{array}$ & 88,88 & 95,61 & 93,10 & 96,42 & 99,22 & 102,09 \\
\hline Soy pate $(200 \mathrm{~g})$ & - & 186,97 & 187,01 & 195,10 & 195,52 & 199,31 \\
\hline Spicy pepper (100 gr) & 74,15 & 104,19 & 90,08 & 100,01 & 101,71 & 107,22 \\
\hline Eggs (piece) & 272,45 & 323,33 & 301,03 & 299,32 & 274,09 & 248,65 \\
\hline $\begin{array}{l}\text { Pasta (corn and wheat - spelt), } \\
(250 \mathrm{~g})\end{array}$ & 150,18 & 175,76 & 185,64 & 173,84 & 174,83 & 174,90 \\
\hline Wheat flour $(\mathrm{kg})$ & 273,90 & 266,79 & 278,30 & 279,03 & 267,67 & 281,13 \\
\hline Corn flour (kg) & 134,62 & 159,43 & 158,32 & 162,59 & 161,93 & 163,67 \\
\hline Rye flour $(\mathrm{kg})$ & 149,60 & 145,46 & 155,79 & 152,97 & 156,22 & 155,80 \\
\hline Oat flour (kg) & 105,05 & 104,22 & 104,92 & 107,00 & 108,33 & 108,81 \\
\hline Barley flour (kg) & 199,78 & 200,13 & 231,24 & 271,52 & 292,05 & 283,73 \\
\hline Spelt flour $(\mathrm{kg})$ & 81,80 & 79,93 & 80,45 & 83,04 & 83,48 & 82,41 \\
\hline Oat bran (200 gr) & 90,85 & 92,73 & 94,75 & 97,22 & 111,41 & 112,75 \\
\hline Fresh milk $(750 \mathrm{ml})$ & - & 135,72 & 137,28 & 140,58 & 149,98 & 150,88 \\
\hline Yogurt $(750 \mathrm{ml})$ & - & 154,98 & 154,09 & 152,71 & 151,69 & 150,70 \\
\hline Sour cream $(150 \mathrm{ml})$ & - & 149,10 & 147,17 & 136,65 & 129,61 & 123,30 \\
\hline Salad (kg) & 78,81 & 80,64 & 61,60 & 77,00 & 82,05 & 89,72 \\
\hline Carrot (kg) & 205,15 & 251,93 & 234,32 & 146,90 & 222,51 & 254,16 \\
\hline Cabbage (kg) & 233,24 & 269,96 & 235,80 & 251,26 & 247,59 & 276,55 \\
\hline Beetroot (kg) & 191,24 & 233,76 & 199,76 & 195,93 & 208,11 & 265,86 \\
\hline Kale (kg) & 127,25 & 133,83 & 148,53 & 137,60 & 127,78 & 155,13 \\
\hline Tomato $(\mathrm{kg})$ & - & - & 149,89 & 123,96 & 115,79 & 112,04 \\
\hline Cucumber (lettuce), (kg) & 118,07 & 115,17 & 104,67 & 108,08 & 108,80 & 127,79 \\
\hline Pepper (kg) & 99,83 & 111,43 & 90,39 & 91,78 & 92,07 & 100,87 \\
\hline Potatoes $(\mathrm{kg})$ & 212,05 & 224,66 & 260,17 & 250,84 & 257,95 & 299,41 \\
\hline Onions (kg) & 382,24 & 283,08 & 297,04 & 286,65 & 293,68 & 354,30 \\
\hline Apple (kg) & - & 209,23 & 219,23 & 198,29 & 218,22 & 235,50 \\
\hline Blueberries (kg) & - & - & - & 133,88 & 146,05 & 145,53 \\
\hline Apricot $(\mathrm{kg})$ & - & - & 126,85 & 113,44 & 119,05 & 130,28 \\
\hline
\end{tabular}

Source: Research-based author calculation. 
The presented results are in accordance with the above mentioned studies of prices of organic products on the basis of which it can be said that the market of these products corresponds, at least in terms of prices, with the markets of developed countries.

\section{Conclusion}

Premium prices have more or less become a "trademark" of organic products and are often referred to when analysing the economic efficiency of organic systems. The results of the research showed that the prices of organic products on the market are, in most cases, higher than the prices of conventional products. The higher prices defined in this way are a consequence of the conditions of supply and demand in the organic market. In developed countries, demand for organic products still outstrips supply. Consumers are prepared to pay premium prices for these products, provided that they imply that basic principles of organic farming are respected in production, which are guaranteed by the organic label.

Premium prices for organic crops are widespread in Western European countries such as Britain, Germany, Denmark and Switzerland, but the size of the premium varies depending on the crop and country. Premium price ranges from 20-150\%.

Similar to developing countries, in the Republic of Serbia, interest in organic production is primarily driven by the economic characteristics, that is, the benefits that producers have, or are under the impression that they have, from organic agriculture. The prices of organic products in the Republic of Serbia have increased compared to the prices of conventional products in the range of $50 \%$ to $300 \%$. The amount of premium price realized depends primarily on the type of product, point of sale and seasonality of the product.

\section{References}

1. Anderson, M. (1994). Economics of Organic and Low-input Farming in the United States of America. In: Lapmkin, N., Padel S. (Eds.), The Economics of Organic Farming: An International Perspective, CABI, Wallingford, UK, pp. 161185.

2. Dabbert, S., Häring, A. M., Zanoli, R. (2003). Organic farming: Policies and prospects. Zed Books, London, UK.

3. Jeong, E., Jang, S. S. (2019). Price premiums for organic menus at restaurants: What is an acceptable level?. International Journal of Hospitality Management, 77:117127. 
4. Jones, D. (2003). Organic agriculture, sustainability and policy. In: Organic agriculture: Sustainability, markets and polices, OECD workshop on organic agriculture, Washington, USA, pp. 17-30.

5. Kovačević, D. (2005). Organsko ratarstvo. U: Organska poljoprivredna proizvodnja (Ur.: Kovačević, D., Oljača, S.), Poljoprivredni fakultet, Univerzitet u Beogradu, Srbija, pp. 35-70.

6. Loke, M. K., Xu, X., Leung, P. (2015). Estimating organic, local, and other price premiums in the Hawaii fluid milk market. Journal of Dairy Science, 98(4):2824-2830.

7. Nieberg, H., Offermann, F. (2003). The profitability of organic farming in Europe. In: Organic agriculture: Sustainability, markets and polices, OECD workshop on organic agriculture, Washington, USA, pp. 141-152.

8. Offermann, F., Nieberg, H. (2000). Economic Performance of Organic Farms in Europe. University of Hohenheim, Hohenheim, Germany.

9. Padel, S., Lampkin, N. (1994). Farm-level Performance of Organic Farming Systems: An Overview. In: Lampkin, N., Padel, S. (Eds.): The Economics of Organic Farming, CABI, Wallingford, UK, pp. 201-221.

10.Pejanović, R., Popović Vranješ, A., Maksimović, G., Tomaš, M., Petrović, D. (2009). Agroeconomical analysis and organic agricultural production. Contemporery Agriculture, 58(3-4):157-164.

11.Rödiger, M., Hamm, U. (2015). How are organic food prices affecting consumer behaviour? A review. Food Quality and Preference, 43:10-20.

12.Sokolov Mladenović, S. (2017). Sustainability and sustainable development in retailing: International and domestic experiences. Economics of Sustainable Development, 1(1):47-56.

13.Sredojević, Z. (2002). Ekonomski problemi ekološke poljoprivrede. Poljoprivredni fakultet, Univerzitet u Beogradu, Srbija.

14.Tomaš Simin, M. (2019). Ekonomski efekti organske proizvodnje u poljoprivredi Republike Srbije. Doktorska disertacija, Poljoprivredni fakultet, Univerzitet u Novom Sadu, Novi Sad, Srbija.

15.Tomaš Simin, M., Miloradić, J. (2014). Some economic indicators of organic agriculture. International Scientific Conference: Sustainable Agriculture and Rural Development in Terms of the Republic of Serbia Strategic Goals Realization Within the Danube Region, thematic proceedings, IAE Belgrade, Serbia, pp. 393-409.

16.Živković, D., Božić Miljković, I., Mihić, S. (2017). Knowledge of French language and culture: A precondition for improving economic relations between Serbia and France. Ekonomika, 63(3):43-53. 